\title{
Irving Babbitt and the Service-Learning Ethic: An Early Critique of Deweyan Progressivism
}

\author{
Kipton D. Smilie \\ Missouri Western State University
}

\begin{abstract}
Service-learning has become an integral component of American education, and scholars continue to debate its definition, purposes, and outcomes. Service-learning in the classroom is not without critics at present, however. This article provides an introductory examination of Irving Babbitt's critiques of the service-learning ethic at its inception in the beginning of the 20th century, particularly of the ideas espoused by John Dewey. This consideration offers an incisive perspective on the service-learning ethic (and its critiques) in our own time.
\end{abstract}

\section{Introduction}

During the past two decades, service-learning has become a mainstay within American colleges and universities. Such programs and course projects are now often a part of a student's experiences at lower levels of education, as well. The virtual explosion of service-learning in American education during the 1990s was a reaction, in part, to the "me" decade of the 1980s, a decade marked by its rampant consumption and self-aggrandizement. Scholarship on service-learning flourished in the 1990s as well (Speck \& Hoppe, 2004), and the American Educational Research Association held its first session on service-learning research in 1994 (Giles \& Eyler, 1994). A number of criticisms, however, have been leveled at the rapid influx of servicelearning programs and related class projects that has swept through American education. Adrianna Kezar and Robert Rhoads (2001), for example, detail complaints they have heard from colleagues concerning service-learning on their campuses. These include concerns about patronizing attitudes of students involved with service-learning projects to how faculty contributions to service-learning are often ignored in tenure guidelines. Mary Hepburn (1997) considers political critiques, noting that Republicans often question the funding and the "coerced volunteerism" service-learning programs and projects seemingly require (p. 141). V.A. Howard (1999) summarizes service-learning critiques from the perspective of the humanities, arguing that many professors question the academic merit of service-learning, the time constraints such projects produce, and the use of class time for servicelearning when students can find such programs elsewhere on campus. Bruce Speck and Sherry
Hoppe (2004) provide a more philosophical consideration of service-learning and its complexities:
[T] he seemingly transparent value of service- learning as a pedagogical initiative to pro- mote community is really not so transparent. Service-learning, it turns out, is not mono- lithic, relying on one theoretical stance unat- tended by complex questions about what the teaching-learning enterprise is all about. In- deed, service-learning is quite controversial, even revolutionary. (p. viii)

The service-learning revolution ultimately began with John Dewey, as he fundamentally influenced the service-learning ethic in the early decades of the 20th century. Scholars are nearly uniform in labeling him as the father of service-learning (Cummings, 2000; Daynes \& Longo, 2004; Deans, 1999; Giles \& Eyler, 1994; Hatcher, 1997; Kezar \& Rhoads, 2001; Maddux \& Donnett, 2015; Saltmarsh, 1996; Speck \& Hoppe, 2004). While Dewey did not advocate for the specific pedagogy of service-learning employed today in classrooms and on campuses, he provided the philosophical basis for service-orientated schooling and educational experiences that eventually evolved into current service-learning practice. The principles advocated by Dewey in the Progressive Era guided educational theorists and practitioners in conceptualizing teaching and learning as a way of engaging in collective and cooperative citizenship (Campbell, 1995). John Saltmarsh (1996), for example, explains that "Dewey's writings inform service-learning through a philosophy of education, a theory of inquiry, a conception of community and democratic life, and a means for individual engagement in society toward the end of social transformation" (p. 13). 
Kezar and Rhoads (2001) point out that "service learning evolved from Dewey's belief that dualisms in philosophy had created a problematic distinction between doing and knowing, emotions and intellect, experience and knowledge, work and play, individual and the world, among other forced dichotomies" (p. 151). The service-learning ethic helped bridge this gap between community and classroom. Some scholars have also pointed to the enormous influence of Jane Addams through the work she and Dewey undertook together in Hull House (Cummings, 2000; Daynes \& Longo, 2004; Morton \& Saltmarsh, 1997; Speck \& Hoppe, 2004).

Like today, critiques of the service-learning ethic at its birth were sparse, but they were certainly present. Scholars, however, have seemingly overlooked some of the arguments against the service-learning ethic in this era, including, especially, those of Irving Babbitt through the lens of his New Humanism. Babbitt (1865-1933), a Romance languages professor at Harvard, co-founded New Humanism as a reactive movement against the Modernist tendencies he saw infiltrating American education and, subsequently, American culture. His New Humanism was founded upon the tenet of control: All individuals possess natural desires for more, whether food, wealth, esteem, or something else. Babbitt (1930) deemed that a "genuine" humanistic education cultivates the individual in placing a check on these expansive desires (p. 25). Babbitt (1919) termed this continuous dualism "the civil war in the cave," and stabilizing this war required proper mediation (p. 130). Babbitt found such humanistic models in the Greek and Roman classics: Those characters who overstepped their bounds, who could not properly control their expansive desires, were punished by the gods. On the contrary, individuals who could practice this inner check led exemplary and blessed lives. Babbitt's concern was that Progressive educators were more interested in encouraging students to look outward rather than inward. The newly born service-learning ethic was certainly one symptom of this philosophical perspective. Babbitt's primary focus on the individual contrasted with Dewey's primary concern with the community, and their oppositional viewpoints can be articulated through their perspectives on this particular service-learning ethic. Such an articulation is perhaps of increased interest today, as the United States's populace is engaged in fundamental disagreements on the country's place and role in the world, and the place and role of its government in the lives of individuals and communities.

The New Humanism movement itself consisted primarily of professors and scholars; all were united in defending humanistic education in the early 20th century (Hoeveler, 1977; Nevin, 1984). Babbitt articulated this conservative position through a number of books and articles during these decades. His unwavering concern was with the anti-humanistic tendencies he thought Modernism was unleashing upon American culture and education. Babbitt specifically targeted Dewey as a central culprit for the destruction of the traditional curriculum, and Dewey eventually wrote a scathing critique of New Humanism in return (Smilie, 2016). Babbitt portrayed Modernist education as an enemy on two fronts: the scientific and the sentimental one. In the scientific realm, Babbitt considered the new research ethic at universities and the rise of social efficiency in the lower schools as symptomatic of Modernism. In terms of the sentimental, Babbitt railed against the new elective system in higher education and the new tendency to base curriculum and courses on student interest in the lower schools. Although seemingly contrary on the surface, Babbitt argued that these two strands were simply opposite sides of the same Modernist coin: both provided no models or principles for placing a check on an individual's expansive tendencies. In fact, Babbitt explained, both actively sought to obliterate this check, as the scientific realm encouraged research and specificity with no bounds, while the sentimental one made sure to place no constraints or inner discipline on students' emotions and feelings.

Service was a fundamental component of both strands. Babbitt explained in 1928 that "modern education" could be "summed up in the words self-expression, vocational training, service. One's doubts about the program converge upon the idea of service" (p. 39). Within the sentimental strand, Babbitt cited the influence of Jean-Jacques Rousseau (1712-78) on this new-found service ethic. In short, for Rousseau, a child's innate goodness came from nature, and, as such, he or she possessed an inherent desire to serve others. Incorporating this service ethic into education was a natural fit. Service then moved into the scientific realm, Babbitt cautioned, as the quest for specificity and expertise operated as a means to ultimately serve others: "What does it matter," Babbitt (1908) asked rhetorically, "if a man in himself is but a poor lop-sided fragment, if only this fragment is serviceable, if only it can be built into the very walls of the Temple of Progress?" (pp. 94-95). Babbitt's concern about this fundamental role played by the service ethic in education stemmed from the avoidance of an inner check. Serving is an expansive activity. Individuals engage in service outside of themselves. This outer expansion was encouraged to the neglect of the inner check. Babbitt argued throughout his career that the consequences of such neglect could be seen in 
his era's rampant imperialism, World War I, and the 1929 Stock Market Crash. While it is difficult, perhaps, to stand against the self-sacrifice of service, particularly within the realm of education, Babbitt (1924) rejoined that "there is something, we should remind the altruist, that the world needs even more than our service, and that is our example" (p. 199).

\section{The Service Ethic's Birth in American Education}

Babbitt's conservative ideas were in direct contrast with the Progressive ethic that was born and cultivated in the early decades of the 20th century. Edward A. Krug (1972), in The Shaping of the American High School, devotes much attention to the reform movements within public schools at the beginning of the 20th century. In his chapter "Social Efficiency Triumphant," Krug examines the tendency in schools to become much more humanitarian in their aims, including the elevation of the concept of "service" within the curriculum. Krug explains that the first part of the 20th century, particularly 1905 and beyond, witnessed a revolution in the curriculum of American schools. Vocational education gradually entered into the curriculum, as advocates sought to provide an education for students, most of whom were not university bound, which was much more practical than the classical curriculum of American schools preceding the 20th century. But as Krug describes:

\footnotetext{
Vocational education was not enough. The spirit of reform in American society demanded an explicit social mission for the school, and many sought to supply its definition. From this came supposedly new doctrines of schooling, reflecting latter-day efforts to resolve the perennial dilemma of the individual and the group. (p. 249)
}

He points out that "One expression of this quest was education for social control; the other, education for social service. Soon they came together in one slogan, education for social efficiency. The new brands of enthusiasm involved schooling on all levels" (p. 249).

What, then, comprised the attempt by schools to advocate "service" beginning in the early 20th century? On a structural level, schools began to operate as "social centers," where the school entered society by providing services to both students and older community members that previously had never been offered. Krug notes that in this period, schools began functioning as social centers by providing health services, baths, and vacation schools. Often those targeted to receive these services were newly arrived immigrants in larger Eastern cities. He explains:

Social centers and social education were seen
largely in the context of social service. Much
the same idea of social service, possibly with
overtones of social control, tended to appear
in the humanitarian aspects of general reform,
particularly in settlement work for immigrants.
(p. 260)

Within this institutional level, the school was able to enter society and actively serve community members. Of course, this shift was just one aspect of the general change from a purely "academic" emphasis in schooling to an education which offered more practicality. What is more practical, clearly, than helping with the immediate needs of the citizens surrounding the school? As Krug adds, "The impulse for humanitarian reform expressed itself partly in settlement houses and other varieties of social work. In addition, it involved two matters of great concern to school people, namely public health and child labor" (pp. 265-266). Compulsory school attendance laws both allowed children to have the opportunity to receive an education and kept them away from the exploitation of factory work. Schools worked diligently within the social realm to provide this "service"; entrance into this social realm was part of the general move toward reform in the Progressive Era. "Humanitarian reform," Krug continues, "in all its phases, including those of social work and service, was part of a protest against the harsh conditions of the laissezfaire way of life" (p. 267). In fact, William J. Reese (1986) explores this function of schools in his Power and the Promise of School Reform: Grassroots Movements during the Progressive Era. He explains:
As new social services and programs entered the public schools after the turn of the centu- ry, many reformers soon endorsed the estab- lishment of "social centers" in neighborhood schools. The simple notion that many innova- tions could be centered in the school encour- aged the belief that the school could become the center of the community: the nucleus of varied social activities. (p. 186)

Ultimately Krug chronicles two levels of the social-efficiency movement within education. For Babbitt, seemingly, schools functioning as social centers would not be overly problematic. After all, even if Babbitt were to ignore the direct good that came from schools functioning as social centers and examine the notion from a strictly academic perspective, it would be hard to disparage a circumstance in which an educational center actively 
sought engagement with the community at large. But it is when schools began to turn their focus internally to "social service" that Babbitt began to be wary. As Krug notes:

Social control was one aspect of the reform movement, but social service was another. The writings of [John] Dewey . . . in this period presented the school much more as an agency of social service than as an agency of social control. (p. 255)

The foundation of social service within the schools was that advocates "concentrated on what would later be called 'the climate of the classroom,' aimed at the development of skills and attitudes needed for cooperative effort both in school and in society" (p. 259).

Herein rested Babbitt's fundamental qualm with service education, as the disciplining of the inner life of the student was given secondary consideration with the primary focus on serving others. In giving primacy to how students were to serve others and contribute to the overall progress of society, Babbitt believed that the ethical center of the student, the mediation of the central dualism of expansion and control, was largely ignored. What then resulted was the creation of groups of humanitarians who had not resolved the struggle of this inner dualism and had no guidance from the wisdom and experience of the past to shape their actions. The ethical education of the individual gradually became ignored, as education became more attuned to how a student was to interact with and serve others, as well as to serve society as a whole. Krug explains that "Even in the service aspects of reform, however, so much emphasis was placed on the social side of life that the result was a massive shift away from individualistic school purposes" (p. 274). In fact, Krug even relates that a superintendent, in 1913, gave "one of the most complete expressions of the idea" of social efficiency, by asserting that "the true purpose" of service education was "not individuality but social unity" (p. 275). Arguably this shift toward procuring "social unity" and away from an education aimed at the individual gained rapid momentum; undoubtedly this movement from the beginning of the 20th century is still continuing strongly at the beginning of the 21 st.

\section{Eliot and Dewey: Advocates for the Service-Learning Ethic}

Babbitt perceived that this service-learning ethic within Progressive education influenced all spheres from the highest philosophical realms of education to, perhaps more alarmingly, elementary school classrooms. He bluntly, if not hyperbolically, explained that

our educational policies, from the elementary
grades to the university, are being controlled
by humanitarians. They are busy at this very
moment, almost to a man, proclaiming the
gospel of service. It will be strange indeed if
dissatisfaction with this situation is not felt
by a growing minority, if a demand does not
arise for at least a few institutions of learning
that are humanistic rather than humanitarian in
their aims. One is at all events safe in affirming
that the battle that is to determine the fate of
American civilization will be fought out first of
all in the field of education. (Babbit, 1930, pp.
$50-51$, emphasis added)

Throughout his writings, Babbit pointed out that the two leading educational figures of the era, Charles W. Eliot and Dewey, both advocated for this service-learning ethic. His contrary position to both Eliot and Dewey in the early decades of the 20th century provides an incisive perspective on the service-learning ethic (and its critiques) in our own time. As President of Harvard during Babbitt's tenure, Eliot (1834-1926) transformed the university through the elective system and a new emphasis on research and specialization, and service played a fundamental role in Eliot's thinking. Babbitt (1932) lamented in this anecdotal illustration of Eliot's core philosophical beliefs: "In an address on the occasion of his ninetieth birthday President Eliot warned his hearers against introspection, lest it divert them from a whole-hearted devotion to service" (p. 228). Babbitt persistently drew attention to Eliot's devotion to service both at Harvard and throughout American education (Smilie, 2012). Babbitt, in his 1929 essay "President Eliot and American Education," mused:
The crucial assumption of President Eliot appears to be that the material efficiency promoted by utilitarian effort will be used altruistically. For the traditional attempt to train for culture and char- acter he sought to substitute, in his own phrase, "training for service and power." (p. 208)

Instead of turning inward, through reading and contemplating the Greek and Roman classics, to mediate the dualism between expansion and restraint, the new Harvard guided students' attention and focus outward. Such a shift made an assumption that Babbitt was hesitant to hold: "Power is in itself desirable provided it be employed to some adequate end. The whole issue is whether service in the humanitarian sense can supply this end. Most Americans are convinced that it not only can but does" (p. 208). 
Babbitt subsequently explained that students at Harvard, and in American education at large, were taught with the focus that learning will "finally be pressed into the service of humanity" (p. 210). Instead of first confronting "the civil war in the cave" within the individual, modern education asked students to initially look outward and toward society in serving others. For the educators following the hallowed and progressive tenets of Rousseau at this time, Babbitt believed that altruism in the form of "service" caused the neglect of the humanistic disciplining of the inner check within individuals. As a result, as Babbitt articulated throughout his works on this promotion of a "service" ethic within education, individuals often ignore their own "civil war in the cave" in their exuberance to be of service to others. This confusion again removes the focus from the inner life of the individual and moves it to an outer, social realm. The question Babbitt (1929) posed concerning Eliot's principle ultimately persisted:

What proof is there, after all, that so purely temperamental a person as President Eliot's theory tends to produce will be altruistic? The humanitarian is finally forced to fall back on some theory of man's natural goodness of the kind that is commonly associated with Rousseau. (p. 211)

Babbitt's concern with Rousseau's ideas and their profound influence upon modern education, particularly regarding the service ethic, led directly to Dewey. Time also played a factor, as Eliot died in 1926, leaving Dewey the most prominent educational philosopher and theorist of the era. Dewey, of course, is considered the father of the servicelearning ethic, and Babbitt clearly noticed and warned about Dewey's influence on service's role in the American curriculum. Babbitt repeated this caution against Dewey's Progressivism throughout his works (Smilie, 2016). At its most fundamental level, Babbitt's critique of Dewey's devotion to the service-learning ethic in education came down to a contention regarding human nature. Babbitt (1924) noted that Dewey proclaimed that "the child is born with a natural desire to give out, to do, to serve," but Babbitt requested that

anyone who has growing children observe them closely and decide for himself whether they exude spontaneously this eagerness for service. Let him then supplement this observation by a survey of the working of the theory on the larger scale for several generations past. (pp. 312-313, emphasis in original)

Babbitt pointed to the historical record for innumerable examples of individuals who clearly did not have or practice a natural desire to serve; in fact, the opposite can often be claimed. Individuals often act with selfish motives in mind. Countries and states do the same, and Babbitt pointed to the imperialism of his day as a refutation, writ large, of this principle. And so, Babbitt (1924) argued, again approaching the hyperbolic:

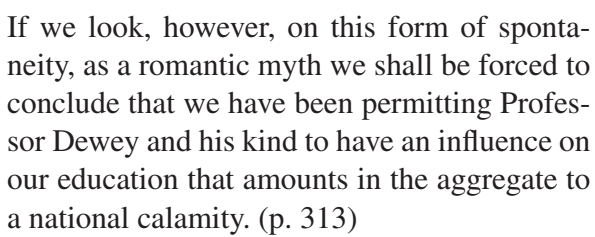

Echoing his question rhetorically posed to Eliot, Babbitt was fundamentally opposed to the idea that individuals are naturally given to service and altruism. These are acts and habits that need to be cultivated, most easily, within formal education, through the study of the humanities. Babbitt (1929) proclaimed that "the amount of instinctive goodness released by the decline of religious and humanistic control has been somewhat exaggerated" (pp. 211-212). As both religious institutions and humanistic education declined in influence in the early decades of the 20th century, Babbitt articulated that hope was placed in the natural goodness of individuals to properly conduct themselves and, consequently, society at large. But as he looked at events occurring during his era, including World War I, the Great Depression, and increasing imperialism worldwide, he concluded that "instinctive goodness" was not enough. Individuals needed to turn inward, not outward. This was Dewey's ultimate error concerning service, according to Babbitt. Dewey fell into the Rousseauist trap. Babbitt (1924) summarized, "The humanitarian is not, I pointed out, primarily concerned, like the humanist, with the individual and his inner life, but with the welfare and progress of mankind in the lump. His favorite word is "service"" (p. 8). Dewey's role as the ostensible founder of the service-learning ethic in American education exemplified his concern with "the welfare and progress of mankind in the lump," but Babbitt continually asked about the tangible results of such an outward focus.

\section{Conclusion}

Babbitt and the New Humanists stood in direct opposition to many Progressivist educational tenets in the beginning of the 20th century, although scholars largely agree that their efforts achieved few practical gains within classrooms (Kliebard, 2004; Nevin, 1984; Panichas, 1999; Ryn, 1997). Babbitt's ideas and works, however, experienced 
a brief rebirth in the 1980 s, as the political conservatism of the country permeated the landscape of education. "A Nation at Risk" was published in 1983, documenting the lowering of both the country's educational standards and students' academic achievement. E.D. Hirsch's advocacy of cultural literacy and William Bennett's pleas to return to a virtue-infused traditional curriculum became prominent components of educational theory. Scholars published three books on Babbitt's (1908) works during this decade, and his Literature and the American College: Essays in Defense of the Humanities was republished in 1986, with an introduction by Russell Kirk (Smilie, 2016). (Interestingly, the 1980s served as the impetus for the new scholarly attention given to service-learning in the 1990s.) But this rebirth was relatively short-lived during the culture wars of this decade. It remains to be seen if Babbitt's works and ideas will reemerge within today's neo-conservative movement. The longing for the past and the concern for individual rights, both gaining political momentum today, would seem to be buttressed by Babbitt's ideas.

Ultimately, the study of Babbitt's critiques of the service-learning ethic can provide insight into today's debate on service-learning practice. As Speck and Hoppe (2004) point out, service-learning continues to prove to be both controversial and revolutionary within American campuses and classrooms. Babbitt's philosophical position from a century away helps to illustrate some of these more contentious components of the service-learning ethic and perhaps brings others to the fore. In today's zeal to engage students with service-learning, are we consequently ignoring other aspects of students' intellectual development? Babbitt would seemingly answer in the affirmative. Babbitt's position also illuminates the curricular battles taking place in the early decades of the 20th century. Through his particular lens of the service-learning ethic, we can better see the larger philosophical conflicts in place regarding the means and ends of education during that era: conformity versus creativity, prescribed versus choice, inward versus outward, constraint versus expansion. Such divisions, of course, are still with us, and Babbitt's traditional and conservative critiques of the service-learning ethic that were born and cultivated during the latter part of the Progressive Era can help us understand today's debates on education as well. The fundamental opposition between Babbitt's and Dewey's ideas can be illustrated through their views on the servicelearning ethic, and this philosophical opposition falls perhaps more within the realm of polarization in today's college campus climate. Issues of social justice, free speech, equal opportunity, cost, and other topics have divided, both philosophically and politically, the campus community, arguably more so than ever in the past. As we join our students in service-learning today, it is important to recognize that such activity has a more complex history than we might expect. In addition, the service-learning ethic evokes philosophical and political conflicts that have flourished in American education throughout the 20th century and now into the 21st. The recognition of both is crucial for the growth and the cultivation of the service-learning ethic moving forward.

\section{References}

Babbitt, I. (1908). Literature and the American college: Essays in defense of the humanities. New York, NY: Houghton Mifflin Harcourt.

Babbitt, I. (1919). Rousseau and romanticism. Cambridge, MA: Riverside Press.

Babbitt, I. (1924). Democracy and leadership. Cambridge, MA: Riverside Press.

Babbitt, I. (1928). Reading with a purpose: French literature. Chicago, IL: American Library Association.

Babbitt, I. (1929). President Eliot and American education. In C. G. Ryn (Ed.), Character and culture: Essays on east and west/Irving Babbitt (pp. 198-224). New Brunswick, NJ: Transaction Publishers.

Babbitt, I. (1930). Humanism: An essay at definition. In N. Foerster (Ed.), Humanism and America: Essays on the outlook of modern civilization (pp. 25-51). New York, NY: Farrar \& Rinehart.

Babbitt, I. (1932). On being creative and other essays. Cambridge, MA: Riverside Press.

Campbell, J. (1995). Understanding John Dewey: Nature and cooperative intelligence. Chicago, IL: Open Court.

Cummings, K. C. (2000). John Dewey and the rebuilding of urban community: Engaging undergraduates as neighborhood organizers. Michigan Journal of Community Service Learning, 7(1), 97-109.

Daynes, G., \& Longo, N. V. (2004). Jane Addams and the origins of service-learning practice in the United States. Michigan Journal of Community Service Learning, 11(1), 5-13.

Deans, T. (1999). Service-learning in two keys: Paulo Freire's critical pedagogy in relation to John Dewey's pragmatism. Michigan Journal of Community Service Learning, 6(1), 15-29.

Giles, D. E., Jr., \& Eyler, J. (1994). The theoretical roots of service-learning in John Dewey: Toward a theory of service-learning. Michigan Journal of Community Service Learning, 1, 177-185.

Hatcher, J. A. (1997). The moral dimensions of John Dewey's philosophy: Implications for undergraduate education. Michigan Journal of Community Service Learning, 4(1), 22-29.

Hepburn, M. A. (1997). Service learning in civic educa- 
tion: A concept with long, sturdy roots. Theory Into Practice, 36(3), 136-142.

Hoeveler, J. D., Jr. (1977). The new humanism: A critique of modern America, 1900-1940. Charlottesville: University of Virginia Press.

Howard, V. A. (1999). The humanities and servicelearning: Whence and whither? Michigan Journal of Community Service Learning, 6(1), 123-132.

Kezar, A., \& Rhoads, R. A. (2001). The dynamic tensions of service learning in higher education: A philosophical perspective. Journal of Higher Education, 72(1), 148-171.

Kliebard, H. M. (2004). The struggle for the American curriculum, 1893-1958 (3rd ed.). New York, NY: RoutledgeFalmer.

Krug, E. A. (1972). The shaping of the American high school, 1920-1941 (Vol. 2). Madison: University of Wisconsin Press.

Maddux, H. C., \& Donnett, D. (2015). John Dewey's pragmatism: Implications for reflection in servicelearning. Michigan Journal of Community Service Learning, 21(2), 64-73.

Morton, K., \& Saltmarsh, J. (1997). Addams, day, and Dewey: The emergence of community service in American culture. Michigan Journal of Community Service Learning, 4, 137-149.

Nevin, T. R. (1984). Irving Babbitt: An intellectual study. Chapel Hill: The University of North Carolina.

Panichas, G. A. (1999). The critical legacy of Irving Babbitt. Wilmington, DE: Intercollegiate Studies Institute.

Reese, W. (1986). Power and the promise of school reform: Grassroots movements during the progressive era. Boston, MA: Routledge \& Kegan Paul.

Ryn, C. (1997). Will, imagination, and reason: Babbitt, Croce and the problem of reality. New Brunswick, NJ: Transaction Publishers.

Saltmarsh, J. (1996). Education for critical citizenship: John Dewey's contribution to the pedagogy of community service learning. Michigan Journal of Community Service Learning, 3(1), 13-21.

Smilie, K. D. (2012). Humanitarian and humanistic ideals: Charles W. Eliot, Irving Babbitt, and the American curriculum at the turn of the 20th century. Journal of Thought, 47(2), 63-84.

Smilie, K. D. (2016). Unthinkable allies? John Dewey, Irving Babbitt and "the menace of the specialized narrowness." Journal of Curriculum Studies, 48(1), 113135.

Speck, B. W., \& Hoppe, S. L. (2004). Introduction. In B. W. Speck \& S. L. Hoppe (Eds.), Service-learning: History, theory, and issues (pp. vii-xi). Westport, CT: Praeger.
Author

KIPTON D. SMILIE (ksmilie@missouriwestern.edu) is an associate professor of education at Missouri Western State University, United States. His interests include humanistic education, curriculum studies, and teacher education. 